Brit. J. vener. Dis. (1965), 41, 147.

\title{
THREE CASES OF POSSIBLE LATE SYPHILIS WITH NEGATIVE
}

\section{TREPONEMA IMMOBILIZATION TEST*}

BY

\author{
J. L. FLUKER \\ Charing Cross Hospital Group $\dagger$
}

Although the treponema immobilization test (TPI) is often an essential requirement in reaching a diagnosis, and as soon as facilities permit should be done in every case of syphilis, it is not inviolable. It would be wrong, for example, to delay treatment in an otherwise undoubted case of syphilitic optic atrophy or general paralysis of the insane simply to await the results of this test. Equally, in an otherwise adequately treated case, a persistently positive TPI is not at present an indication for further treatment. Conversely, indications for treatment may exist with a negative TPI, as in the three following cases (all under my care) at the Royal Infirmary, Chester, between 1956 and 1962 inclusive.

\section{Case Reports}

Case 1, a woman aged 36, was referred in 1956 when three months' pregnant because she had a positive WR of which she was aware. Her only previous pregnancy twelve years before had resulted in a healthy girl. Nine years before, her husband had had sero-positive primary syphilis with a penile chancre which had left an obvious scar. During the two weeks after the appearance of the sore, but before medical advice was sought, he had had repeated intercourse with his wife. The diagnosis being confirmed by dark-ground and serological findings, he had been fully treated and cured and all reactions were negative in 1956. His wife had had two negative blood tests a fortnight apart, the last three weeks after her last exposure. Despite reminders from the clinic she then defaulted, but had worried ever since and was now convinced that she was "unclean".

Clinical examination was normal and blood tests were reported as follows: WR positive 1 in 32; Meinicke and Kahn positive; cardiolipin WR positive; PPR positive 1 in 4; but RPCFT and TPI negative. Ordinarily, such a patient would be discharged with a diagnosis of biologic

* Short paper read at the MSSVD meeting in Dublin. May 29-30, 1964.

+ Formerly at the Royal Infirmary, Chester. false positive (BFP), but in the existing circumstances, and after full discussion with the patient, treatment was decided upon of 10 daily injections of PAM (crystalline penicillin $G)$, totalling 6 mega-units.

The baby was normal and, after pregnancy, the mother's tests were reported: WR positive 1 in 4; Kahn weakly positive; and Meinicke negative. Two years later (1958) the WR was positive 1 in 64; Kahn, Meinicke, and CLWR all positive; but RPCFT and TPI were both negative. The CSF was normal and she was discharged.

Four years later (1962) she was referred again, this time with candidiasis. The pattern of serological results was exactly similar; an additional PPR was negative. Full clinical examination with chest $x$ ray and blood count disclosed no abnormality and she was in excellent health. Although the correct diagnosis was probably a chronic BFP, the antecedents and, above all, the patient's state of mind, made treatment necessary.

Case 2, an ex-army officer aged 68 years, was referred by a general physician because aortic incompetence had been discovered during a routine medical examination. There was a history of sero-positive primary syphilis in 1935 for which he stated that he had received three courses of arsenic and bismuth. He had defaulted but believed that his last WR had become negative. Examination showed an unmistakable scar in the coronal sulcus. Additionally he had a loud aortic diastolic murmur with BP $170 / 70$ and a Corrigan-type pulse. There was no clinical cardiac enlargement, nor any evidence of cardiac insufficiency or arteriosclerosis, local or generalized.

Radiologically, the aortic arch was prominent and the ECG showed slight left ventricular preponderance. The ESR was $8 \mathrm{~mm}$. and all the serological tests, reagin and treponemal, were negative. The CSF was normal. He denied that he had ever had penicillin and there was no past history of rheumatic fever or any unexplained pyrexia. The patient was convinced that the underlying process was syphilitic and, agreeing that this was probable though not certain, he was treated with a preliminary course of bismuth and iodides followed by daily injections of PAM, totalling 18 mega-units. Six years later he was alive and well and the clinical findings were unchanged. 
Case 3, a widow aged 45 years, was referred in 1958. As a result of her one and only pregnancy in 1942 a son was born with active congenital syphilis, for which he had been fully treated in the Chester Clinic and discharged as cured. At the age of 16 years, desirous of joining the Royal Navy, he was found to have certain stigmata of congenital syphilis and was referred back to his original clinic for a report, following which he was accepted for naval service without reservation.

His mother, who, since the WR was negative in 1942 had been discharged forthwith without any treatment, also attended and was investigated further. There was no relevant past history; clinical examination disclosed no abnormalities and the serological findings, both reagin and treponemal, were entirely negative. CSF findings confirmed this, except for protein of $55 \mathrm{mg}$. per cent. and a slight increase in globulin which, the laboratory commented, might be a technical error. Nine months later, the protein had risen to $95 \mathrm{mg}$. per cent. with a considerable increase in globulin. The TPI was negative both in blood and CSF. The patient remained very well and as investigations, including urine analysis, full blood count, and chest and skull $x$ rays, disclosed no abnormalities, a tentative diagnosis of latent neurosyphilis was made and, after a preliminary course of iodide and bismuth, she was given daily penicillin to a total of 18 mega-units of PAM. Nine months later the CSF protein was $30 \mathrm{mg}$. per cent. and the globulin not in excess. In 1962 a similar result being obtained, the patient was finally discharged.

While it cannot be claimed that the diagnosis was proved, nevertheless, it seems probable. Certainly syphilis still presents interesting problems for solution.

\section{Summary}

Three cases with negative TPI tests are presented in which, the possibility of late latent or late syphilis not being excluded for a variety of reasons, it was thought desirable to give treatment. In these days of precise and essential laboratory diagnosis, the general clinical and social background of the patient must never be forgotten.

Trois cas de syphilis tardive probable

où le test d'immobilisation du tréponème est négatif

\section{RÉSUMÉ}

On présente trois cas où le test d'immobilisation du tréponème est negatif et où la possibilité d'une syphilis latente tardive ou d'une syphilis tardive n'étant pas exclue pour différentes raisons on jugea préférable de traiter le malade.

En ces jours où le diagnostic précis de laboratoire est essentiel on ne doit jamais oublier le contexte clinique et social du malade. 